\title{
IDENTIFIKASI RAWAN BENCANA TANAH LONGSOR KABUPATEN TORAJA UTARA
}

\author{
Ega Londongallo ${ }^{1}$, Maxi Tendean ${ }^{2}$, Grace F. E. Suoth ${ }^{3}$ \\ ${ }^{1}$ Mahasiswa Program Studi Geografi, Fakultas Ilmu Sosial, Universitas Negeri Manado \\ ${ }^{2,3}$ Dosen Program Studi Geografi, Fakultas Ilmu Sosial, Universitas Negeri Manado \\ e-mail: egalondongallo99@gmail.com
}

\begin{abstract}
North Toraja Regency is an area that is prone to landslides with a potential zone of medium to high ground movement, which has resulted in damage to land transportation routes between districts being cut off, damage to buildings, and loss of lives. The focus of this research is to determine the level of vulnerability and map the class of landslide hazards in the North Toraja Regency. This type of research is descriptive qualitative with Geographical Information Systems (GIS) approach and then analyzed by overlay and scoring (weighting). Based on data processing, the study produced a landslide hazard map in North Toraja Regency with five classes of vulnerability, namely: very low area of $58,049 \mathrm{~km}^{2}(50 \%)$, low area of 118,087 $\mathrm{km}^{2}(11.18 \%)$, medium area of $256,057 \mathrm{~km}^{2}(22.07 \%)$, rather high area of 195,872 $\mathrm{km}^{2}(16.07 \%)$, very high area of $11,972 \mathrm{~km}^{2}(1.03 \%)$.
\end{abstract}

Keywords: Hazard, Landslide, Mapping, Geographical Information Systems (GIS)

\begin{abstract}
Abstrak: Kabupaten Toraja Utara merupakan daerah yang rawan akan longsor dengan zona potensi gerakan tanah menengah hingga tinggi, yang mengakibatkan kerusakan jalur trasportasi darat antar kecamatan terputus, kerusakan bangunan, hingga hilangnya korban jiwa. Fokus penelitian bertujuan untuk menentukan tingkat kerawanan dan memetakan kelas kerawanan bencana tanah longsor di Kabupaten Toraja Utara. Jenis penelitian adalah deskriptif kualitatif dengan pendekatan metode sistem informasi geografis (SIG) kemudian dianalisis secara overlay dan scoring (pembobotan). Berdasarkan pengolahan data, penelitian menghasilkan peta kerawanan bencana tanah longsor secara relatif di Kabupaten Toraja Utara dengan lima kelas kerawanan, yaitu: sangat rendah seluas $58.049 \mathrm{~km}^{2}(50 \%)$, rendah seluas $118.087 \mathrm{~km}^{2}(11,18 \%)$, sedang seluas $256.057 \mathrm{~km}^{2}(22.07 \%)$, agak tinggi seluas $195.872 \mathrm{~km}^{2}(16.07 \%)$, sangat tinggi seluas $11.972 \mathrm{~km}^{2}(1.03 \%)$.
\end{abstract}

Kata Kunci: Kerawanan, Tanah Longsor, Pemetaan, Sistem Informasi Geografis (SIG)

\section{PENDAHULUAN}

Bencana ialah peristiwa atau rangkaian peristiwa yang mengancam dan mengganggu kehidupan dan penghidupan masyarakat yang disebabkan, baik oleh faktor alam dan/atau faktor non alam maupun faktor manusia sehingga mengakibatkan timbulnya korban jiwa manusia, kerusakan lingkungan, kerugian harta benda, dan dampak psikologis. Bencana dapat dibedakan menjadi tiga antara lain bencana alam, bencana non alam dan bencana sosial (UU RI No. 24 Tahun 2007 tentang Penanggulangan Bencana).

Indonesia merupakan salah satu negara rawan akan bencana, dikarenakan secara geologis terletak pada zona ringfire (zona pengunungan sirkum pasifik dan laut india).
Keberadaan zona ini mengakibatkan munculnya gunung api, intrusi, patahan dan lipatan yang menyebabkan keanekaragaman morfologi di Indonesia. Daerah dengan morfologi berbukit dan bergunung di Indonesia memiliki tingkat resiko tanah longsor yang tinggi dan kejadian tanah longsor akan semakin meningkat pada musim penghujan akibat perubahan massa tanah oleh air hujan (Dwi, 2008).

Badan Geologi Kementerian ESDM (2016) mengemukakan bahwa Kabupaten Toraja Utara merupakan daerah yang rawan akan longsor dengan zona potensi gerakan tanah menengah hingga tinggi. Curah hujan yang tinggi juga merupakan faktor yang sangat mempengaruhi terjadinya bencana tanah longsor. 